\title{
Soft Skills Practice by Company Representatives in Implementing Procedures before The Departure of Umrah and Ziarah Pilgrims in Malaysia
}

Mohd Sabri Jamaludin, S. Salahudin Suyurno and Khairul Azhar Meerangani

To Link this Article: http://dx.doi.org/10.6007/IJARBSS/v11-i12/11835

DOI:10.6007/IJARBSS/v11-i12/11835

Received: 10 October 2021, Revised: 13 November 2021, Accepted: 28 November 2021

Published Online: 11 December 2021

In-Text Citation: (Jamaludin et al., 2021)

To Cite this Article: Jamaludin, M. S., Suyurno, S. S., \& Meerangani, K. A. (2021). Soft Skills Practice by Company Representatives in Implementing Procedures before The Departure of Umrah and Ziarah Pilgrims in Malaysia. International Journal of Academic Research in Business and Social Sciences, 11(12), 976-994.

Copyright: (c) 2021 The Author(s)

Published by Human Resource Management Academic Research Society (www.hrmars.com)

This article is published under the Creative Commons Attribution (CC BY 4.0) license. Anyone may reproduce, distribute, translate and create derivative works of this article (for both commercial and non0-commercial purposes), subject to full attribution to the original publication and authors. The full terms of this license may be seen at: http://creativecommons.org/licences/by/4.0/legalcode

Vol. 11, No. 12, 2021, Pg. 976 - 994

Full Terms \& Conditions of access and use can be found at http://hrmars.com/index.php/pages/detail/publication-ethics 


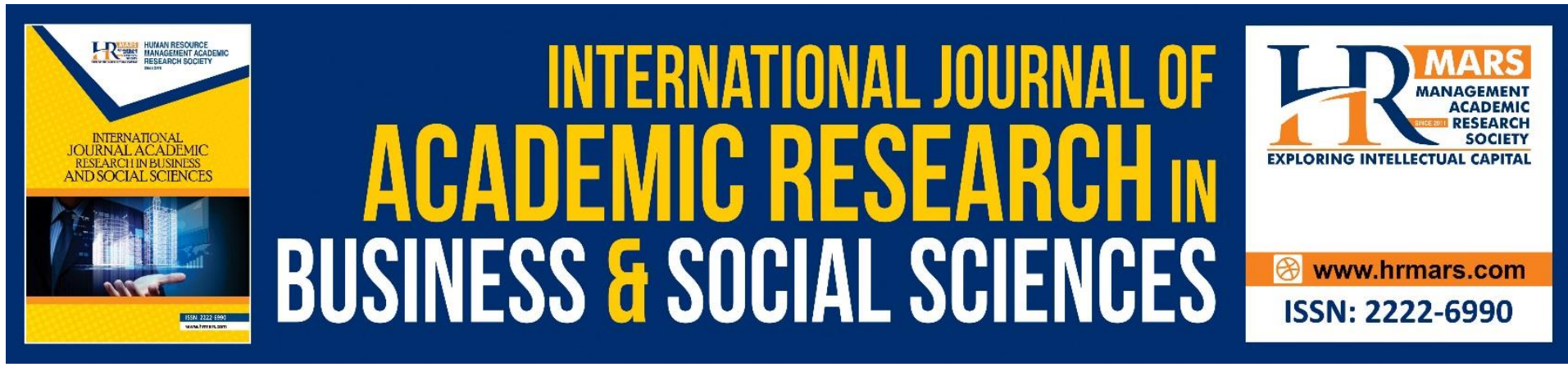

\title{
Soft Skills Practice by Company Representatives in Implementing Procedures before The Departure of Umrah and Ziarah Pilgrims in Malaysia
}

\author{
Mohd Sabri Jamaludin, S. Salahudin Suyurno and Khairul \\ Azhar Meerangani \\ Academy of Contemporary Islamic Studies (Acis) Universiti Teknologi Mara (UiTM), Melaka \\ Branch, Alor Gajah Campus, KM 26 Jalan Lendu, 78000 Alor Gajah Melaka, Malaysia
}

\begin{abstract}
Company representatives or better known as individuals who are skilled in managing and carrying out procedures regarding umrah and ziarah is a career that is gaining attention in Malaysia. However, the study related to the representatives of this company is not done much because there may be many individuals and groups of society who do not have knowledge about this field. The main objective of this study was to examine the soft skills of company representatives in carrying out procedures before departure. This study uses a quantitative method that uses a questionnaire as a method of data collection. This form is distributed on a regular basis online due to limitations in the increasingly contagious Covid-19 pandemic. The questionnaire instrument of this study takes a holistic perspective on soft skills based on the 7 elements of Soft Skills issued by the Ministry of Higher Education Malaysia (2006). The constructed questionnaire set was validated by reference experts in the umrah and guidance industry. Quantitative data analysis in this study using Statistical Package For Social Science (SPSS) version 26. The results of the study found that only communication, leadership and moral skills as well as ethics recorded a high mean value compared to other soft skills. This shows that the company representative still does not have the perfect and complete competencies and skills in terms of soft skills when performing the umrah procedure before departure. These findings will then be implemented as a benchmark to company representatives who make this NOSS a career guide to improve their skills and economics, thus becoming more competitive. This study is seen to increase the benefits to specific industries in producing mutawwif that follow the specifications and needs of the industry. Also, benefits to the government in contributing to the Gross Domestic Product (GDP) of the country.
\end{abstract}

Keywords: Company Representative, Soft Skills Practice, Umrah and Pilgrimage, Umrah Agency 


\section{Introduction}

The practice of Soft Skills is one of the elements of knowledge that must be mastered by every individual involved in the service sector, especially in jobs involving umrah and pilgrimage services (Jamaludin \& Bakar, 2021). Umrah and pilgrimage is an act of worship that is highly demanded by Islam. This is further evidenced by the presence in the five (5) pillars of Islam, namely performing Hajj for those who can afford it (Abdul Rahman, 2018).

ولله على الناس حج البيت من استطاع إليه

Meaning: "And God requires people to perform the pilgrimage to the House is one that is able to reach him."

(Sura`Ali-Imran (3): Verse 97)

Umrah pilgrims are clients or customers who use the services of an umrah operator or umrah operator. Of course, the preparation required by the company in ensuring that the relevant matters of the Congregation are followed completely and perfectly without fail. Failure can have a profound effect on the Congregation barred to the Holy Land. Thus, the company representative is the main character who helps the Congregation in realizing the wishes and desires of the Congregation to go to the Holy Land.

Therefore, all implementation and preparation in heading to the Holy Land should be given priority. Especially for company representatives. Company representatives are individuals who are responsible for managing and assisting all procedures that help pilgrims to depart for the Holy Land starting from the aspects of documentation, baggage handover, briefings and management at the airport (Abdul Rahman, 2018).

Performing Umrah is not the same as traveling, although it is called Islamic tourism. Umrah is defined as going to Baitullah (Mecca) accompanied by the intention to perform Umrah by performing certain pillars and conditions until perfect (Mohd et al., 2020). This is evidenced by the rewards that rocketed for those who worship with sincerity and humility in the Holy Land of Mecca and Medina through the Hadith of the Prophet Muhammad:

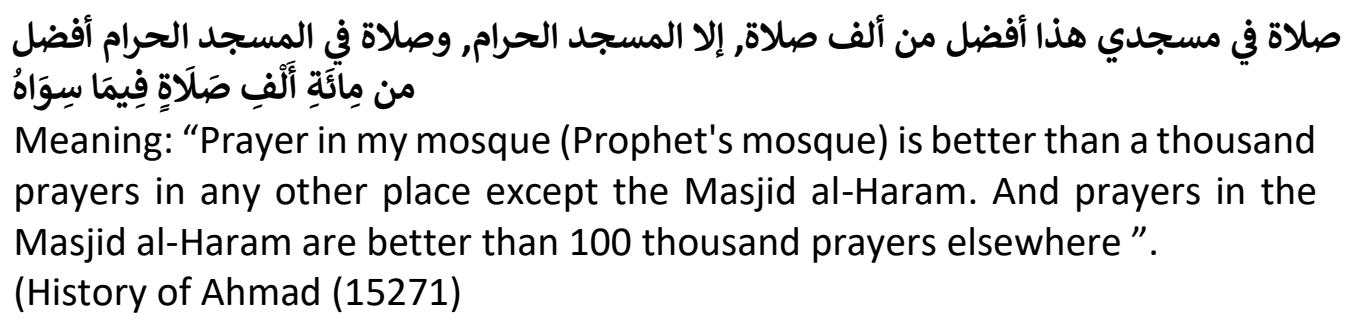

Therefore, this study will focus on the Practice of Soft Skills among Company Representatives in Implementing the Procedure of the Pilgrimage Before Departing to Perform Umrah in the Holy Land. Researchers would like to see the level of mastery of soft skills practices mastered by company representatives who assist them in performing congregational procedures before departure.

\section{Problem Statement}

The umrah and ziarah industry is an industry that often gets attention by the Malaysian government through the Ministry of Arts and Culture Malaysia (MOTAC) and also the establishment of the Umrah Regulatory Council (MKSU) along with several other government 
agencies is seen as an entity that responsible for taking care of the management of umrah and ziarah in Malaysia (Afendi \& Mohamad, 2010).

The following are some of the problems that arise in the management of the pilgrims before departure at the airport:

1. Lack of information and accurate information for the pilgrims to gather at the airport along with the position and location of gathering that is suitable for monitoring and supervision by company representatives representing umrah companies to their Congregation.

2. The lack of concern for the welfare aspects of the Congregation by the company during the stay at the airport such as the comfort of the Congregation, the safety of the Congregation, the health of the Congregation and the food and drink of the Congregation.

3. The unattractive personality shown by the company representatives in carrying out duties throughout the airport is quite worrying such as untidy clothes, impolite manners as well as unprofessional communication conveyed to the Congregation.

4. The care of the property and assets of the pilgrims were not taken seriously such as 24 -inch and 20 -inch trolley bags placed in front of the counter for the purpose of check in luggage which were scattered and feared to be exchanged with other umrah agencies using the same flight to the Holy Land.

5. The company representative did not use loudspeakers allowed by the Airport when briefing the Congregation, this has had a negative impact on the Congregation who sit far away that is not clearly listening to instructions and get important information from company representatives.

6. The insensitivity of company representatives in maintaining the "Spiritual Quotient $(S Q)$ " and "Emotional Quotient (EQ)" among the pilgrims who have waited a long time at the airport before they left.

7. The responsibility of the umrah operator in ensuring that all pilgrims have no restrictions on Immigration check in through checks in the system https://sspi.imi.gov.my/SSPI/. This is important so that the pilgrims do not feel frustrated and hindered over factors that should have been resolved early before they depart by the umrah operator company.

Thus, through the problems mentioned above, it can be concluded that the role and responsibilities that need to be played by company representatives contribute greatly to the good image of the company as well as provide smoothness in carrying out management procedures before departure at the airport.

This problem is seen to be due to the lack of soft skills possessed by company representatives when performing tasks (Zainal \& Hassan, 2018). This shortage has a negative and adverse effect as well as causing dissatisfaction of the Congregation registered under their company. The image and reputation of the company will be bad in the future.

\section{Research Objectives}

a. Identify the practice of soft skills of company representatives required in implementing the Procedure of the Congregation Before Departing to Perform Umrah in the Holy Land.

b. Analyze the practice of soft skills of company representatives required in performing the Procedure of the Congregation Before Departing to Perform Umrah in the Holy Land. 
c. Build a model practice soft skills representative of the company in carrying out the necessary procedures for the Congregation Before Departure Performing Ibadah Umrah in the Holy Land.

\section{Research Questions}

a. Is the practice of soft skills representative of the company in carrying out the necessary procedures for the Congregation Before Departure Performing Ibadah Umrah in the Holy Land?

b. Is the analysis of the practice of soft skills representative of the company in carrying out the necessary procedures for the Congregation Before Departure Performing Ibadah Umrah in the Holy Land?

c. Is the model practice soft skills representative of the company in carrying out the necessary procedures for the Congregation Before Departure Performing Ibadah Umrah in the Holy Land?

\section{Scope of The Study}

This study focuses on soft skills among company representatives focused on umrah and pilgrimage agencies located in Negeri Sembilan only.

The selected agency is a registered legal agency and there are no problems related to performance and problems regarding the services offered to umrah pilgrims refer to the List of Tourism Operating Licenses and Travel Agencies (TOBTAC), 2018). This agency must have a license that lists fields such as Inbound (I), Outbound (O), Ticketing (T) and Umrah (U) or known as IOTU.

The researcher will select respondents consisting of company representatives who have the following criteria:

\begin{tabular}{|l|l|r|}
\hline 1. & Gender & $\bullet$ Male and Female \\
\hline 2. & Age & $\bullet 18$ and above \\
\hline 3. & $\begin{array}{l}\text { Experience as a } \\
\text { Company } \\
\text { Representative }\end{array}$ & $\bullet \begin{array}{l}\text { Minimum 3 Years of service in a Legal } \\
\text { Registered Umrah Operator Company }\end{array}$ \\
\hline
\end{tabular}

Table 1.0 : Criteria for Selection of Company Representatives in Malaysia

\section{Research Design}

This study is a quantitative study using survey method and data taken with how to distribute questionnaires. This study chose the questionnaire method because this method can save time to collect data in a short period of time. Julie Yu and Cooper (1983) stated that the questionnaire method can provide better understanding in the study of management practices than other methods. The researcher has constructed a set of questionnaires that cover a number of things that touch on the research questions to be answered by the respondents.

\section{Sampling}

Selection of the study sample was randomly selected from a population determined using the sample size determination table from the method of Krejie and Morgan (1970). Coakes et al 
(2006) stated 100 respondents as the sample size for acceptable factor analysis. While Ding et al (1995) argue that sample sizes between 100 to 150 are already good enough. However, it depends on the respondents involved in a study to be conducted by the researcher and not all are suitable.

The following is a list of Sendirian Berhad (Sdn.Bhd) companies that have IOTU license areas in Malaysia by state (MOTAC, 2021):

\begin{tabular}{|l|l|l|}
\hline NO. & NAME OF STATE & $\begin{array}{l}\text { NUMBER OF HEADQUARTERS (HQ) } \\
\text { OF UMRAH OPERATORS WHO } \\
\text { HAVE 'IOTU' LICENSE (UMRAH) }\end{array}$ \\
\hline $\mathbf{1 .}$ & Wilayah Persekutuan Kuala Lumpur & 60 \\
\hline $\mathbf{2 .}$ & Wilayah Persekutuan Labuan & 0 \\
\hline $\mathbf{3 .}$ & Wilayah Persekutuan Putrajaya & 1 \\
\hline $\mathbf{4 .}$ & Selangor & 101 \\
\hline $\mathbf{5 .}$ & Negeri Sembilan & $\mathbf{1 4}$ \\
\hline $\mathbf{6 .}$ & Melaka & 18 \\
\hline $\mathbf{7 .}$ & Johor & 23 \\
\hline $\mathbf{8 .}$ & Perak & 12 \\
\hline $\mathbf{9 .}$ & Pulau Pinang & 7 \\
\hline $\mathbf{1 0 .}$ & Kedah & 30 \\
\hline $\mathbf{1 1 .}$ & Perlis & 0 \\
\hline $\mathbf{1 2 .}$ & Terengganu & 9 \\
\hline $\mathbf{1 3 .}$ & Kelantan & 22 \\
\hline $\mathbf{1 4 .}$ & Pahang & 4 \\
\hline $\mathbf{1 5 .}$ & Sabah & 7 \\
\hline $\mathbf{1 6 .}$ & Sarawak & 9 \\
\hline & & \\
\hline $\mathbf{0 V E R A L L ~ T O T A L}$ & $\mathbf{3 1 7}$ \\
\hline
\end{tabular}

Table 2.0: Number of Headquarters (HQ) of Umrah and Pilgrimage Operators for Each State in Malaysia (Source: MOTAC Web Portal)

Number of respondents proposed is 2 people for one umrah and pilgrimage agency. If referred to Table 2.0 above, the number of agencies that exist in Negeri Sembilan is 14 . According to table 3.0, a large number of total populations can be represented with a certain sample size. It can be seen that the number of population for this study was 28 people. The number 28 is close to the total population of 30 of which the sample size is 28 samples. So the researcher set the total sample size and also the population is 28 people who will be involved in this study.

\section{Research Process}

The study flow chart below describes the entire case research process that will be conducted. The research process tells what the researcher will do starting from the initial stage of the research until the research is completed or the findings of the research are obtained. 
INTERNATIONAL JOURNAL OF ACADEMIC RESEARCH IN BUSINESS AND SOCIAL SCIENCES Vol. 11, No. 12, 2021, E-ISSN: 2222-6990 @ 2021 HRMARS

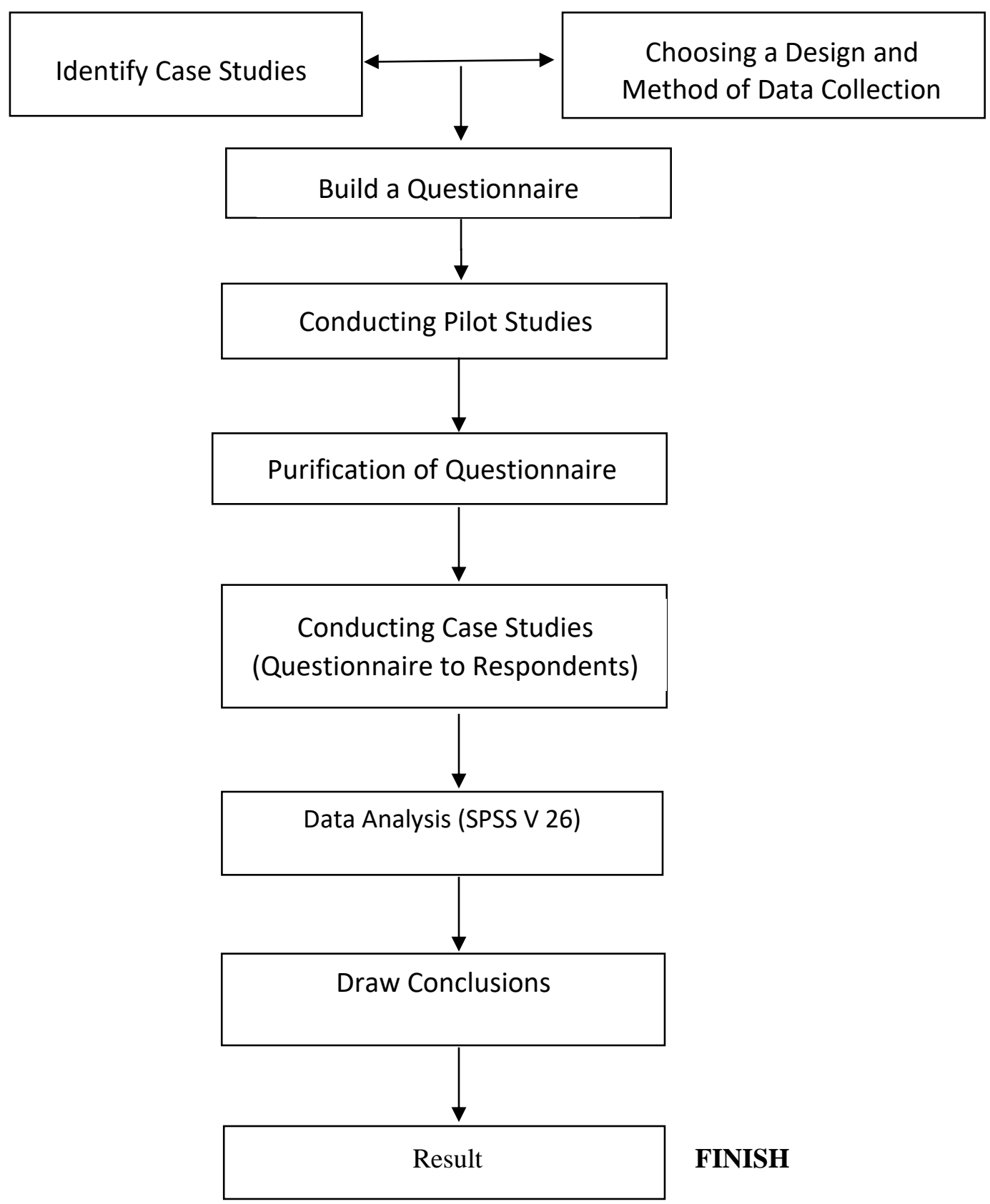


Figure 1.0: Research Process Flow

\begin{tabular}{|c|c|c|c|c|c|c|c|c|c|}
\hline \multicolumn{10}{|c|}{ TABLE FOR DETERMINING SAMPLE SIZE FROM A GIVEN POPULATION } \\
\hline $\mathrm{N}$ & $S$ & $\mathrm{~N}$ & S & $\mathrm{N}$ & S & $\mathrm{N}$ & S & $\mathrm{N}$ & $\mathrm{S}$ \\
\hline 10 & 10 & 100 & 80 & 280 & 162 & 800 & 260 & 2800 & 338 \\
\hline 15 & 14 & 110 & 86 & 290 & 165 & 850 & 265 & 3000 & 341 \\
\hline 20 & 19 & 120 & 92 & 300 & 169 & 900 & 269 & 3500 & 246 \\
\hline 25 & 24 & 130 & 97 & 320 & 175 & 950 & 274 & 4000 & 351 \\
\hline 30 & 28 & 140 & 103 & 340 & 181 & 1000 & 278 & 4500 & 351 \\
\hline 35 & 32 & 150 & 108 & 360 & 186 & 1100 & 285 & 5000 & 357 \\
\hline 40 & 36 & 160 & 113 & 380 & 181 & 1200 & 291 & 6000 & 361 \\
\hline 45 & 40 & 180 & 118 & 400 & 196 & 1300 & 297 & 7000 & 364 \\
\hline 50 & 44 & 190 & 123 & 420 & 201 & 1400 & 302 & 8000 & 367 \\
\hline 55 & 48 & 200 & 127 & 440 & 205 & 1500 & 306 & 9000 & 368 \\
\hline 60 & 52 & 210 & 132 & 460 & 210 & 1600 & 310 & 10000 & 373 \\
\hline 65 & 56 & 220 & 136 & 480 & 214 & 1700 & 313 & 15000 & 375 \\
\hline 70 & 59 & 230 & 140 & 500 & 217 & 1800 & 317 & 20000 & 377 \\
\hline 75 & 63 & 240 & 144 & 550 & 225 & 1900 & 320 & 30000 & 379 \\
\hline 80 & 66 & 250 & 148 & 600 & 234 & 2000 & 322 & 40000 & 380 \\
\hline 85 & 70 & 260 & 152 & 650 & 242 & 2200 & 327 & 50000 & 381 \\
\hline 90 & 73 & 270 & 155 & 700 & 248 & 2400 & 331 & 75000 & 382 \\
\hline 95 & 76 & 270 & 159 & 750 & 256 & 2600 & 335 & 100000 & 384 \\
\hline \multicolumn{10}{|c|}{$\begin{array}{l}\text { Note: } \quad \text { "N" is population size } \\
\text { " } \mathrm{S} \text { " is sample size. }\end{array}$} \\
\hline \multicolumn{10}{|c|}{$\begin{array}{l}\text { Krejcie, Robert V...Morgan, Daryle W. "Determining Sample Size for Research Activities". } \\
\text { Educational and Psychological Measurement. } 1970 \text {. }\end{array}$} \\
\hline
\end{tabular}

Table 3.0: Table of sample size determinants by Krejcie \& Morgan (1970)

\section{Response Rate}

The respondents of this study are representatives of companies from umrah and ziarah agencies in Malaysia that have been selected independently. Only 28 respondents were involved. All forms received can be used.

The table shows the response rates of the study.

\section{Description}

Total Percentage (\%)

Total questionnaires distributed

Total questionnaires returned

Total questionnaires returned but not used
28

28

0

0.0

Total questionnaires used $28 \quad 100.0$

Table 4.0 : Respondent Response Rate

\section{Data Clearance}

Errors in compiling and entering data in computer programs such as SPSS is a common occurrence for researchers. This is unavoidable and always happens despite researchers being careful. Before any analysis is done, data cleaning is done to ensure that the data is clean. This data cleaning is done by looking at the minimum, maximum and average for each item to ensure that the data is within the proper data range. All data is within the proper answer range and no data is corrupted. 


\section{Demographic Analysis of Respondents}

In this section, the researcher will analyze the background of respondents according to various levels of demographic forms, namely age, academic qualifications and years of experience as a company representative. All the background information of these respondents is based on the researcher's respondents, namely, company representatives from various umrah and pilgrimage agencies in Negeri Sembilan as many as 28 questionnaires were received back.

The demographic profile analysis for this study can be summarized in the table below.

How Many Years of Experience as a Company Representative

\begin{tabular}{|c|c|c|c|c|c|}
\hline & & Frequency & Percent & $\begin{array}{l}\text { Valid } \\
\text { Percent }\end{array}$ & $\begin{array}{l}\text { Cumulative } \\
\text { Percent }\end{array}$ \\
\hline \multirow[t]{3}{*}{ Valid } & 3-5 Years & 16 & 57.1 & 57.1 & 57.1 \\
\hline & $\begin{array}{l}5 \text { Years and } \\
\text { Above }\end{array}$ & 12 & 42.9 & 42.9 & 100.0 \\
\hline & Total & 28 & 100.0 & 100.0 & \\
\hline
\end{tabular}

Table 5.0 : Years of Experience as a Company Representative

Company representatives with between 3 to 5 years of experience recorded the highest number of 57.1 percent. Meanwhile, company representatives with experience aged 5 years and above recorded the lowest percentage of 42.9 percent. This also shows that a career in the field of management of mutawwif umrah and ziarah is a career that gets the attention of many people who want to tame directly or indirectly.

\begin{tabular}{|c|c|c|c|c|c|}
\hline & & Frequency & Percent & Valid Percent & Cumulative Percent \\
\hline \multirow[t]{4}{*}{ Valid } & 21-30 Years & 7 & 25.0 & 25.0 & 25.0 \\
\hline & 31-40 Years & 17 & 60.7 & 60.7 & 85.7 \\
\hline & 41-50 Years & 4 & 14.3 & 14.3 & 100.0 \\
\hline & Total & 28 & 100.0 & 100.0 & \\
\hline
\end{tabular}

Table 5.1 : Age of Company Representatives

While the age of company representatives between 31 years to 40 years is the highest age recorded a percentage of 60.7 percent, followed by age 21 years to 30 years with a 
percentage of 25.0 percent. The smallest and lowest percentage was recorded by mutawwif aged over 41 to 50 years with 14.3 per cent.

\section{Academic Qualifications}

\begin{tabular}{|c|c|c|c|c|c|}
\hline & & Frequency & Percent & Valid Percent & Cumulative Percent \\
\hline \multirow[t]{5}{*}{ Valid } & Diploma & 11 & 39.3 & 39.3 & 39.3 \\
\hline & Master/PhD & 3 & 10.7 & 10.7 & 50.0 \\
\hline & Bachelor & 11 & 39.3 & 39.3 & 89.3 \\
\hline & SPM & 3 & 10.7 & 10.7 & 100.0 \\
\hline & Total & 28 & 100.0 & 100.0 & \\
\hline
\end{tabular}

Table 5.2 : Academic Qualifications of Company Representatives

Approval of academic achievement is an element that drives the understanding of company representatives in performing better and quality assignments prior to departure. The table above, recorded the same percentage of value for Diploma and Bachelor's academic qualifications which is 39.3 percent. This percentage has recorded the highest percentage. Meanwhile, SPM and Master/PhD approvals also recorded the same amount of 10.7 percent. It can be understood that, the company representative instrument has a good academic background that is starting SPM and above.

\section{Instrument Reliability Analysis (Cronbach's Alpha)}

Through the collection of data received by the researcher, the most important analysis done is to measure or validate the reliability value according to the items in the questionnaire. This validity and reliability analysis was conducted to ensure that the questionnaire has stability for use by the community. This reliability analysis was measured using Cronbach Alpha. The closer the Alpha value is to the value of 1 , it indicates that the item has a high reliability value.

Cronbach alpha is a numerical coefficient to represent reliability. It is used to identify the level of consistency of the questionnaire instrument with values above 0.70 is categorized as high in its reliability. The higher the reliability of an instrument, the lower the degree of error of the instrument. Therefore, a research instrument is said to be reliable even if the measurements are made repeatedly but the results given remain the same. 


\begin{tabular}{l|l|l}
\multicolumn{2}{l}{ Reliability Statistics } \\
$\begin{array}{l}\text { Cronbach's } \\
\text { Alpha }\end{array}$ & $\begin{array}{l}\text { Cronbach's Alpha Based on } \\
\text { Standardized Items }\end{array}$ & $\begin{array}{l}\text { N } \\
\text { of Items }\end{array}$ \\
\hline .771 & .799 & 42 \\
\hline
\end{tabular}

\section{Table 6.0: Analysis of Cronbach's Alpha}

The conclusions of the instrument constructed by the researcher for this study prove that the high reliability and the small degree of error.

\section{Descriptive Analysis of Study Variables}

In this section, the researcher will analyze and identify descriptive data based on the questions in the questionnaire that have been answered by the respondents. This descriptive analysis was used to look at the distribution of values for each variable.

\begin{tabular}{ll} 
MIN RANGE & \multicolumn{1}{c}{ CATEGORIES } \\
\hline 1.00 to 2.33 & Less effective and needs to be improved \\
2.34 to 3.67 & Moderate and needs to be considered for improvement \\
3.68 to 5.00 & Good \\
\hline
\end{tabular}

Table 7.0 : Interpretation of Mean Scores

Refer to the table below, showing the results of descriptive analysis for all variables:

Table 7.1: Communication Skills

\begin{tabular}{llc}
\hline Items & Mean & Achievement Category \\
\hline $\begin{array}{l}\text { 1. I often communicate in language } \\
\text { relaxed and easy to without changing } \\
\text { understand meaning of sentences. }\end{array}$ & 4.21 & Good \\
$\begin{array}{l}\text { 2. I like to share and give advice } \\
\text { useful to Umrah pilgrims who } \\
\text { deal with me. }\end{array}$ & 3.68 & Good \\
$\begin{array}{l}\text { 3. I will start communication with } \\
\text { Umrah and Pilgrimage }\end{array}$ & 3.32 & Moderate and Need To Be \\
Pilgrims to Before They Start. \\
$\begin{array}{l}\text { 4. I will communicate with info and } \\
\text { information that is really accurate } \\
\text { and authentic. }\end{array}$ \\
$\begin{array}{l}\text { 5. I feel confident that skills } \\
\text { communication will facilitate } \\
\text { all procedures before departure for } \\
\text { Umrah and pilgrimage. }\end{array}$
\end{tabular}


Results of mean score analysis for Communication Skills in table 7.1. There are 5 items measuring the communication skills of company representatives. The activities of the company representative at the Airport before the departure of the Umrah pilgrims were measured to measure the communication skills of the company representative. 3 out of 5 communication skills items exhibited the best achievement category, while the other 2 items were in the moderate achievement category and needed to be considered for improvement.

Table 7.2 : Leadership Skills

\begin{tabular}{|c|c|c|}
\hline Items & Mean & Achievement Category \\
\hline $\begin{array}{l}1 . \quad \text { I have the nature of being } \\
\text { responsible for the instructions and } \\
\text { assignments given by the company to } \\
\text { me when performing the procedure } \\
\text { before departure. }\end{array}$ & 4.07 & Good \\
\hline $\begin{array}{l}\text { 2. I reserve the right to ensure that } \\
\text { the Congregation gathers Manner at } \\
\text { the location of focus in a timely } \\
\text { for dissemination of information. }\end{array}$ & 2.68 & $\begin{array}{l}\text { Moderate and Need To Be } \\
\text { Considered For Improvement }\end{array}$ \\
\hline $\begin{array}{l}3 . \quad \text { I don't like a selfish Congregation } \\
\text { prioritizing personal affairs without } \\
\text { any sense courtesy to other Congregations. }\end{array}$ & 4.04 & Good \\
\hline $\begin{array}{l}4 . \quad \text { I do not like the Congregation } \\
\text { which is chatty and deliberately } \\
\text { creates provocation to make things worse. }\end{array}$ & 4.07 & Good \\
\hline $\begin{array}{l}\text { 5. I like to be respected by the } \\
\text { congregation and colleagues. }\end{array}$ & 2.82 & $\begin{array}{l}\text { Moderate and Need To Be } \\
\text { Considered For Improvement }\end{array}$ \\
\hline
\end{tabular}

Results of the mean score analysis for Leadership Skills in table 7.2. There are 5 items measuring leadership skills in company representatives. The activities of company representatives at the Airport before the departure of the Umrah pilgrims were measured to measure leadership skills among company representatives. 3 out of 5 leadership skills items exhibited the best achievement category, while the other 2 items were in the moderate achievement category and needed to be considered for improvement. 
Table 7.3 : Teamwork Skills

Items

1. I am ready to shoulder and accept the task to work without problems.

2. I don't mind myself feeling tired and-workers my work results are liked by co.

3. I am willing to be appointed to be a leader or follower when working with a team.

4. I be creative in distributing tasks by urgent needs priorities present when duty considered
Mean Achievement Category

Moderate and Need To Be Considered For Improvement

Moderate and Need To Be Considered For Improvement

Moderate and Need To Be Considered For Improvement

Moderate and Need To Be Considered For Improvement

The results of the mean score analysis for Teamwork Skills in table 7.3. There are 4 items measuring Teamwork skills on company representatives. The activities of company representatives at the Airport before the departure of the Umrah pilgrims were measured to measure Teamwork skills among company representatives. All 4 items of Teamwork skills exhibit moderate achievement categories and should be considered for improvement. 
Table 7.4 : Moral Skills and Professional Ethics

\begin{tabular}{lll}
\hline Items & Mean Achievement \\
Category & & \\
\hline
\end{tabular}

1. I am always careful in duty and prioritize ethics and morals when dealing Considered To with the Congregation.

2. I will lose patience if the counter officer check-in Baggage at KLIA deliberately delays baggage my Congregation for no reason.

3. Polite, neat and unobtrusive clothing is suitable clothing for company representatives. Good to wear while on duty even if uncomfortable.

4. Priority of greeting and always sweet face is applied when necessary and not all the time working at KLIA.

5. I agree that smoking is immoral and unethical
Moderate and Need To Be Considered For Improvement
4.04

Good

Good

4.00
Less effective and needs to be improved

The results of the mean score analysis for Professional Moral Skills and Ethics in table 7.4. There are 5 items measuring the Moral and Professional Ethics skills of a company representative. The activities of the company representative at the Airport before the departure of the umrah pilgrims were measured to measure the Moral and Professional Ethics skills of the company representative. 3 out of 5 items of Professional Moral and Ethics skills exhibited the best achievement category, while the other 2 items were in the moderate achievement category and needed to be considered for improvement. 
Table 7.5 : Critical Thinking Problem Solving Skills

\begin{tabular}{lll}
\hline \multicolumn{1}{c}{ Items } & Mean & Achievement \\
Category & & \\
\hline
\end{tabular}

1. Pictures of the Congregation

are not enough when managing

Visa will make me Considered To

Quit despair and bored Improved

2. I will be responsive and responsible to Congregational Complaints against luggage that is lost while at KLIA due to my negligence and prepared to make compensation.

3. Congregants who come to KLIA to check in will be left without any effort for contact them

4. Lack of info and information due to the congregation not being present during the departure briefing session. I will contact and make a video call to brief in private.

5. Jemaah facing documentation problems and health at the last minute when you want to take off at the airport would be advisable for professional of the Cabinet and considered for the Cabinet safety when in the Holy Land Added Good
3.64

Good

Moderate and Need To Be Considered For Improvement
4.25

Good

Good

Good

The results of the mean score analysis for Critical Thinking Problem Solving Skills in table 7.5. There are 5 items measuring the Critical Thinking Problem Solving skills of a company representative. The activities of the company representative at the Airport before the departure of the umrah pilgrims were measured to measure the Critical Thinking Problem Solving skills of the company representative. 2 out of 5 items of Critical Thinking Problem Solving skills exhibited the best achievement category, while the other 3 items were in the moderate achievement category and needed to be considered for improvement. 
Table 7.6 : Information Management Skills \& Continuous Learning

\begin{tabular}{lll}
\hline Items Mean Achievement \\
Category
\end{tabular}

1. I like to attend effective management courses for the purpose of increasing knowledge.

2. I do not feel happy with the ratings givenby the Congregation for the quality of my umrah services provided to me.

3. I am always updated on the latest Technology to facilitate management and procedures before departure are presented to the Umrah and my pilgrimage.

4. I don't care about money to top up knowledge for learning purposes .
Moderate and Need To Be Considered For Improvement

Moderate and Need To Be

3:18 Considered For Improvement Good

The results of the mean score analysis for Information Management Skills and Continuous Learning in table 7.6. There are 4 items measuring the Information Management and Continuous Learning skills of company representatives. The activities of the company representative at the Airport before the departure of the umrah pilgrims were measured to measure the Information Management and Continuous Learning skills of the company representative. 1 out of 4 items of Information Management and Continuous Learning skills exhibited the best achievement category, while 2 more items were in the moderate achievement category and needed to be considered for improvement and 1 item in the Less effective achievement category needed to be improved. 
Table 7.7: Entrepreneurial Skills

\begin{tabular}{|c|c|c|}
\hline Items & Mean & Achievement Category \\
\hline $\begin{array}{l}\text { 1. I wisely take the opportunity to fit } \\
\text { know the Congregation for publicity purposes. }\end{array}$ & 3.61 & $\begin{array}{l}\text { Moderate and Need To Be } \\
\text { Considered For Improvement }\end{array}$ \\
\hline $\begin{array}{l}2 . \quad \text { I also have skills like making } \\
\text { pictures, photocopy and fill in the form of } \\
\text { wages for Jemaah that needs outside of } \\
\text { office hours. }\end{array}$ & 3.71 & Good \\
\hline $\begin{array}{l}\text { 3. I can also talk and deliver } \\
\text { courses related to the implementation of umrah, } \\
\text { procedure and umrah motivation to the public. }\end{array}$ & 4.00 & Good \\
\hline $\begin{array}{l}\text { 4. I am aggressive in finding Jemaah } \\
\text { and registering them to be Jemaah umrah and earn }\end{array}$ & 3.46 & $\begin{array}{l}\text { Moderate and Need To Be } \\
\text { Considered For Improvement }\end{array}$ \\
\hline
\end{tabular}
commission from the company.

The results of the mean score analysis for Entrepreneurial skills in table 7.7. There are 4 items measuring the entrepreneurial skills of company representatives. The activities of the company representative at the Airport before the departure of the Umrah pilgrims were measured to measure the entrepreneurial skills of the company representative. 2 out of 4 items of entrepreneurial skills exhibited the best achievement category, while the other 2 items were in the moderate achievement category and needed to be considered for improvement.

In conclusion, the mean values of communication skills, leadership skills and professional moral and ethical skills recorded the highest average among the seven variables. While critical thinking problem solving skills and entrepreneurial skills occupied the second highest average mean value. Next, the mean value of teamwork skills and lastly the lowest mean value is information management skills and continuous learning.

This clearly shows that the mastery of soft skills among company representatives shows not the mastery of an excellent and good level. It also shows that only certain skills recorded high values while others were moderate and low. 
Build a model practice soft skills needed a company representative Jemaah Implementing Procedures Prior to Departure Performing Ibadah Umrah in the Holy Land.

MUTAWWIF COMPETENCE UNIT (N791: 001-4: 2016) - CU

National Employee Skills Standard (NOSS) Management of Mutawwif Umrah and Ziarah Skills Development Department (JPK), Ministry of Human Resources Malaysia

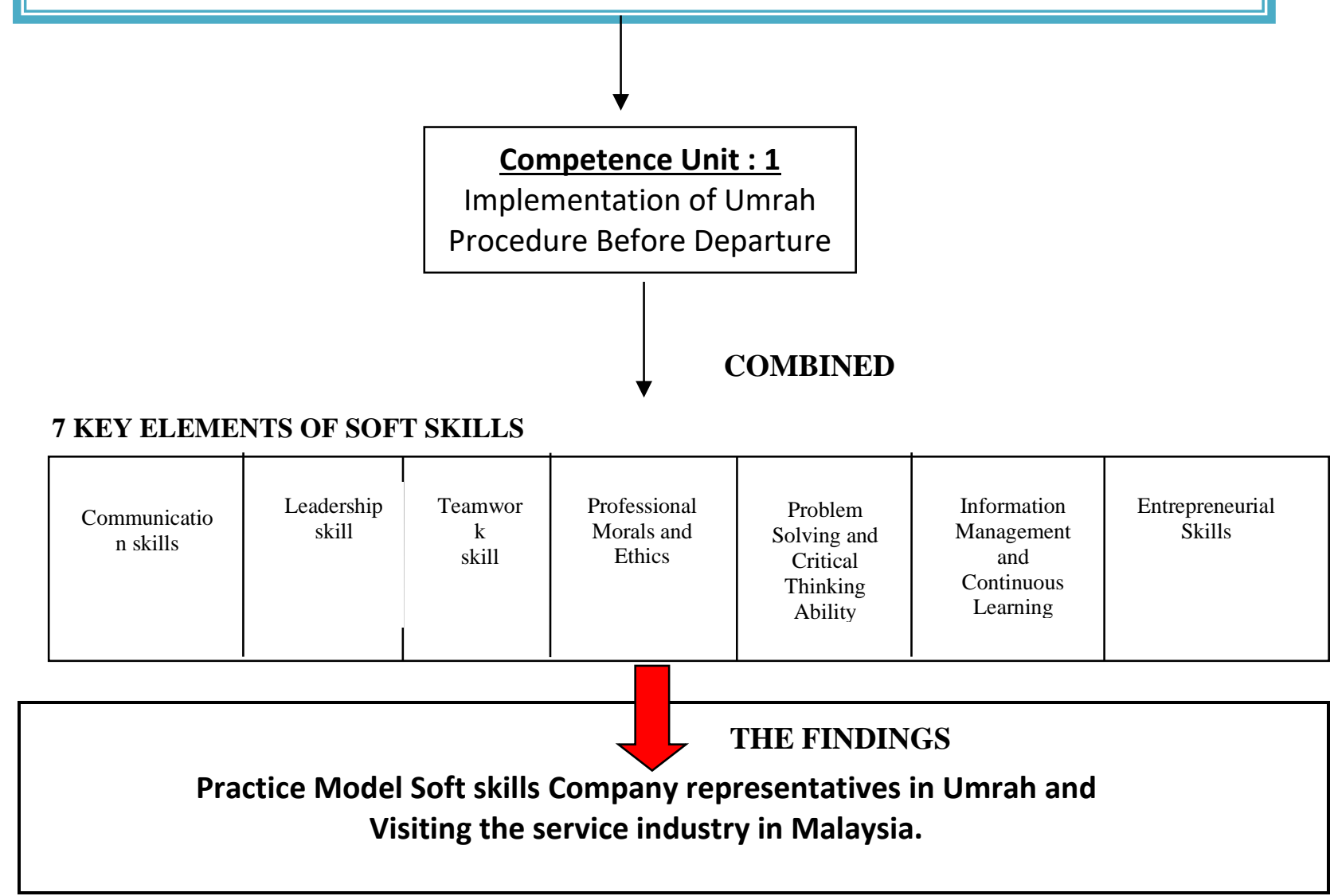

Figure 2.0: The framework of this study is taken from the Model from the Umrah and Ziarah Mutawwif Management Competency Unit in the National Employee Skills Standard (NOSS) Level 4 by the Department of Skills Development (2016) and the Institute of Higher Education Soft Skills Model (2006)

\section{Conclusion}

This study is a rare study done in a specific study related to the practice of soft skills of company representatives in performing congregational procedures before departure. The results of the analysis also showed that the majority of respondents agreed with the researcher's questions and this study has achieved its objectives and answered all the questions stated at the beginning of this study. Overall, this study has explained about the form of soft skills on the practices of company representatives that need to be mastered in developing skills in the task as a company representative in the management of mutawwif umrah and pilgrimage procedures before departure. 


\section{Acknowledgement}

We would like to thank the people involved in making this article published. Do not forget the faculty and university to trust us. Finally, thanks to our family and friends who have supported us all this time.

\section{Corresponding Author}

Mohd Sabri Bin Jamaludin

Academy of Contemporary Islamic Studies (Acis) Universiti Teknologi Mara (UiTM), Melaka Branch Melaka , Alor Gajah Campus, KM 26 Jalan Lendu, 78000 Alor Gajah Melaka, Malaysia Email: uitmsabri.2021@gmail.com

\section{References}

Al-Quran Karim

Abdul Rahman, H. (2018). Potential and Challenges in Developing Islamic Tourism in Malaysia. Journal of Sultan Alauddin Sulaiman Shah, Special Issue, 506-518.

Abdullah, M. A., Ali, N., Aznie, R., Rose, C., Fuad, M., \& Jali, M. (2012). The tourism and environment industry in Port Dickson: highlighting the balance point between demand and supply. Geography: Malaysian Journal of Society and Space, 8(7), 135-146.

Johan, A. I., Zaki, M. A. (2010). Border Tourism: Potential and Challenges Cross-Border Tourism: Potential and Challenges. Proceedings of Perkem V, Volumes 2, 2, 260-272.

Jamaludin, M. S., \& Bakar, N. R. A. (2021). Studying the Practice of Mutawwif in the Assignment of Guiding Umrah Pilgrims in Malaysia. International Conference on Syariah \& Law2021 (ICONSYAL 2021), 2021(April), 136-149.

Yu, J., \& Cooper, H. (1983). A Quantitative Review of Research Design Effects on Response Rates to Questionnaires. Research Article, 20(1), 36-44

Mapjabil, J., Razak, R. R. A., Marzuki, M., \& Zainol, R. M. (2015). Islamic tourism: a conceptual overview and its relevance in Malaysia. Geography: Malaysian Journal of Society and Space, 11(1), 172-182.

Mohd, H., Hashim, J., Wan Khairuldin, W. M. K. F., Alwi, E. A. Z., \& Reshad, H. F. M. (2020). Lembaga Tabung Haji's Guidance Method for Malaysian Hajj Pilgrims: A Preliminary Assessment. Journal of Islam and Contemporary Society, 21(1), 55-67. https://doi.org/10.37231/jimk.2020.21.1.397

Saadah, I. (2012). The level of understanding and practice on the obligation to cover the aurat among students in three religious secondary schools in Pekan district. In Open University of Malaysia. Open University Malaysia.

Zainal, S. R. M., \& Hassan, S. H. (2018). Understanding the Individual Motivations and Barriers of Malaysian Mutawwif. International Academic Journal of Social Sciences, 05(02), 6875. https://doi.org/10.9756/iajss/v5i2/18100027 